Jurnal ASPIKOM, Vol. 6, No. 1, January 2021, pp. 42-60

P-ISSN: 2087-0442, E-ISSN: 2548-8309

DOI: http://dx.doi.org/10.24329/aspikom.v6i1.825

\title{
The Dynamics of Public Sphere in Social Media: Cybermedia Analysis
}

\section{Dinamika Ruang Publik dalam Media Sosial: Sebuah Analisis Media Siber}

\author{
Petrus Ana Andung 1*, Maria V. D. P. Swan ${ }^{2}$ \\ ${ }^{1,2}$ Universitas Nusa Cendana, address of institution/affiliation \\ *Corresponding author, e-mail: petrusanaandung@staf.undana.ac.id
}

\begin{abstract}
Social media use in Indonesian society has increased rapidly. One of the Facebook groups formed by the netizens of Nusa Tenggara Timur (NTT), who actively build virtual discussions, is the NTT Baru Facebook Group with 86,783 followers. This article aims to analyze the public sphere dynamics that occur in this Facebook group. This qualitative approach used cybermedia analysis methods. The results showed that the Facebook group was a forum for NTT netizens to virtually gather and freely discussing public service issues in NTT Province. The Group was a virtual public space for NTT netizens to demonstrate democratic practices to reflect civil society's increasing control function. The Group's existence was used as a political communication instrument in building social mobilization and as moral and political support for the governor and deputy governor of NTT, Viktor Laiskodat and Josef Nae Soi.
\end{abstract}

Keywords: Cybermedia Analysis; NTT Baru Facebook Group; Public Sphere; Social Media

\begin{abstract}
Abstrak
Penetrasi penggunaan media sosial dalam masyarakat Indonesia mengalami peningkatan pesat. Salah satu group Facebook bentukan warganet NTT yang secara aktif membangun diskusi-diskusi di ruang maya adalah group Facebook dengan nama NTT Baru dengan total 86.783 followers. Artikel ini bertujuan untuk menganalisis dinamika ruang publik yang terjadi dalam group Facebook NTT Baru. Penelitian ini menggunakan pendekatan kualitatif dengan metode analisis media siber. Hasil penelitian menunjukkan, group Facebook NTT Baru merupakan salah satu wadah berkumpulnya warganet NTT untuk secara bebas mendiskusikan masalah-masalah layanan publik dalam lingkup Provinsi NTT secara virtual. Group Facebook NTT Baru menjadi ruang publik virtual bagi netizen NTT dalam mempertunjukkan praktik demokrasi sebagai cerminan dari meningkatnya fungsi kontrol masyarakat sipil. Keberadaan group Facebook NTT Baru dimanfaatkan sebagai salah satu sarana komunikasi politik dalam membangun mobilisasi sosial sebagai bentuk dukungan moril dan politis para pendukung terhadap kepemimpinan Gubernur dan Wakil Gubernur NTT, Viktor Laiskodat dan Josef Nae Soi.

Kata Kunci: Analisis Media Siber; Grup Facebook NTT Baru; Media Sosial; Ruang Publik
\end{abstract}




\section{Introduction}

The growth of the internet in Indonesia is very surprising. The total active users as of January 2019 reached 150 million, or around 56\% of Indonesia's total population. When compared with Indonesia's population of 265 million, $57 \%$ of them are social media users. Of these internet users, at least 142.8 million users have internet access using mobile devices (Websindo, 2019).

The trend of internet use, especially those based on mobile internet or smartphones, provides space for the growing number of social media users, including Facebook. People freely have accounts on various social media platforms. According to data from APJII, users of internet content in Indonesian society until 2018 were dominated by Facebook, namely 50.7\% (APJII, 2019).

The high penetration of social media users, especially Facebook in Indonesia, is triggered by the ease of accessing the internet. Moreover, the social networking site is one of the new trends in society; even its presence received significant interest (Wijayanti, 2020). This social networking application also provides space for its users freely without time limits to connect and share information quickly and instantly (Kindarto, 2010). The desire of its users to network and expand relationships has triggered an increasing trend in the use of Facebook in Indonesian society (Sulthan \& Istiyanto, 2019).

In addition to providing features to expand social networks, the Facebook application also provides convenience in obtaining (accessing) and sharing information. However, apart from the positives provided by this social media platform, it does not escape the negative impacts it has caused. For instance, starting from health problems due to disproportionate allocation of time, dissipation, and often triggering rifts in social relations with others (Raliana et al., 2018).

Nevertheless, despite its weaknesses, Facebook is often used as a means of communication to build learning and social change in society. In fact, this application is considered quite popular in various circles worldwide (Juju \& Sulianta, 2010). The presence of the main Facebook application in modern society has succeeded in changing the way of communicating. Moreover, today's presence of social media with a wide selection of features is totally different from conventional communication technologies (Sulianta, 2015). Users can freely express their opinions, aspirations, ideas, and more via Facebook. This condition then creates public spaces in the virtual world(Heryanto, 2018).

The use of public space on Facebook is evident through the proliferation of groups formed in accordance with the similarities in their area of origin, hobbies, interests, affiliations, and others. The formation of the Facebook group often plays a role in accommodating the various interests of the members who are members of it (Hastuti \& Rahmawati, 2019).

One of the Facebook groups in NTT that is actively building discussions in cyberspace is the Facebook group with the name NTT Baru with a total of 86,783 followers as of 31 March, 2020. In this Facebook group, followers freely discuss various issues that are developing around East Nusa Tenggara (https://www.facebook.com/groups/120152055419903, nd). Based on researchers' observations, this Group generally discusses public service issues ranging from policy issues to government programs at the provincial level of East Nusa Tenggara (NTT). Uniquely, this Facebook group uses photos of the Governor and Deputy Governor of NTT Province, but this Group's initiative and ownership do not officially represent the 
NTT Provincial Government. Even so, the group members seemed enthusiastic in exchanging ideas about the direction of development in this province so that they did not hesitate to provide input for the NTT Provincial Government. For this reason, this article aims to analyze the dynamics of the public space that occurs in the NTT Baru Facebook group.

Research on the Facebook phenomenon has been conducted by previous researchers. Waziz, for example, has his research entitled "Facebook as a Political Communication Media: Dr. Faida, MMR's Facebook CyberMedia Analysis". The results of Waziz's research show that Dr. Faida, MMR's new Facebook media is an effective political communication medium to convey government policy messages to the public. Social media Facebook is claimed to be a channel for public messages in responding to the Jember regent's policies to be an alternative political communication between the authorities and the people of Jember. However, the Facebook cybermedia still does not represent the aspirations of all Jember residents (Wazis, 2017).

Budiyono conducted another research entitled Social Media and Political Communication: Social Media as Political Communication Ahead of the 2017DKI Jakarta Regional Election. The results found that social media, especially Facebook, can be a means of political communication that is quite effective in the process of democratic life during the 2017 DKI Jakarta Pilkada (Budiyono, 2016).

Based on these two studies, it appears that Facebook social media is quite instrumental as a medium of political communication to convey citizen aspirations and build political support. Therefore, these two previous studies are the entry points for the need for this research to further examine the dynamics of cyber public spaces in discussing various social phenomena and public services both among users and admins and fellow users.

The term public space or public sphere was introduced by Habermas through his work The Structural Transformation of The Public Sphere; An Inquiry into a Category of Gourgeus Society. In Habermas's view, public space is a specific domain as an arena where people as part of civil society meet, discuss, and exchange information freely about anything to produce general views or public opinion (Habermas, 1989).

Public space is needed so that social life can strengthen democratic practice. It is through the public sphere that the control function of civil society over state administration can be carried out properly (Prasetyo, 2012).

Talking about public space is closely related to discussing the citizens. In the context of publicity, it is the citizenry or what is commonly known as civil society as the main actor or actor of communication (Hardiman, 2010). Therefore, the key elements of the public sphere in civil society are social equality (Syahputra, 2013).

Meanwhile, virtual space or cyberspace has implications for what Jones refers to as a "new public space". The characteristics of this digital public space encompass various structures of human life, from personal encounters to intercultural or crosscultural encounters. According to Camp and Chien, virtual space is not the same as space in traditional media and is not the same as public space in real space. Cyberspace provides opportunities for internet users to create new methods of communication in every aspect of people's lives(Nasrullah, 2018).

This research uses the social construction of technology (SCOT) theory. According to Leonardi, Barely, and Humphreys, this theory asserts that technology does not shape humans. On the contrary, it is human action that shapes technology because technology, whatever its kind, is a social, political, economic and environmental 
product (Yousefikhah, 2017).

This social construction of technology theory carries several key concepts: flexibility, relevant social groups, technological frameworks, and stabilization ( $\mathrm{Li}$, 2008). According to the perspective of the SCOT theory, technology should be seen from its artifact aspects and its social aspects. This means that the emergence of technology can never be separated from humans' social construction who created it. Therefore, the usefulness of technology for its users will be greatly influenced by the extent to which the technology's presence is perceived (Ida, 1999).

\section{Method}

This research used a qualitative approach. The research method used is cybermedia analysis. Methodologically, this cybermedia analysis is another variant of a research based on virtual ethnography or netnography. In practice, this method combines online and offline sides in the research process. Each level of analysis in cybermedia analysis will provide guidance in analyzing the condition of virtual communities on the internet. Therefore, this method helps researchers study cyber-based media technology both from the micro aspect, namely the text level, and the macro aspect or its social context (Nasrullah, 2018).

The unit of analysis in this research is all user and admin posts and comments in the NTT Baru Facebook group in the March 2020 period. Issues are limited to public service issues in NTT, especially health and the environment. The March 2020 post was used as a unit of analysis because Coronavirus 2019 or Covid-19 began to enter and become a hot conversation in Indonesian society since March 2020. Since then, the narrative that has been built among netizens has begun to bloom not only with the Covid-19 issue but also related to environmental comfort aspects.

The research subjects were the administrators (admin) of the New NTT Facebook Group and the groups' members. The selection of informants was carried out with criteria and considerations, including being actively involved in disseminating information and/or providing responses to the New NTT Facebook Group, having gender representation, and being a member of the NTT Baru Facebook group for at least three years.

Data in this study were collected using a combination of in-depth interview techniques, document review, and virtual observations. In-depth interviews were conducted to find out the user and admin perspectives of the NTT Baru Facebook group. Meanwhile, observations on the NTT Baru Facebook Group page were also carried out to understand the communication process that was built up virtually among netizens who are members of the NTT Baru Facebook group.

Data were analyzed using cybermedia analysis framework. As Nasrullah introduced, cybermedia analysis is carried out at four levels: media space, media documents, media objects, and experiences. At the media space level, the focus of his analysis is on social media Facebook as an entity where it acts as an instrument that facilitates social interactions among netizens. Second, the media document level guides the researchers in understanding how content in Facebook groups is produced, disseminated, and spoken about in cyberspace. Third, the media object level examines the context surrounding the birth of the text. Fourth, the experience level relates to the NTT Baru Facebook group members' real-day experiences concerning the text produced and distributed. 


\section{Results and Discussion}

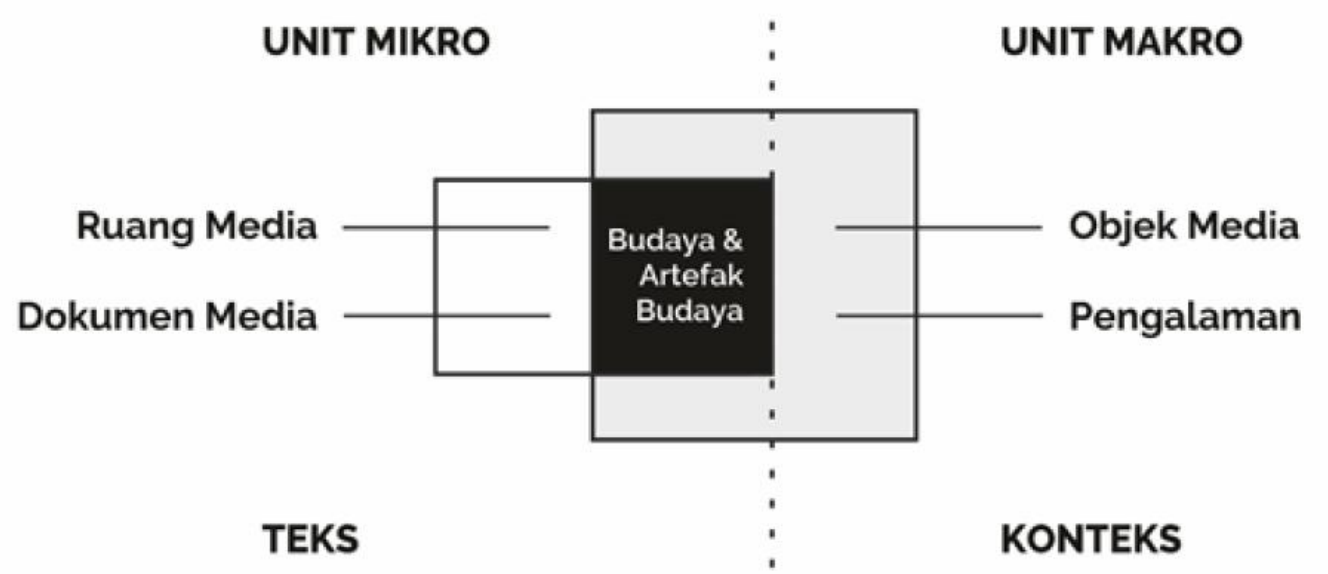

Figure 1. Cybermedia Analysis Framework Model (Nasrullah, 2018)

Cybermedia analysis is a new variant in communication research methods to analyze the phenomenon of cybermedia, especially regarding the production of messages, interpretations, and communication interactions that occur in cyberspace. This cybermedia analysis method includes two levels, namely, micro and macro media. The micro level focuses on observing media text, which includes media space or media space and media documents or media archives. Meanwhile, the level of social context consists of media objects or media objects and experiences or experiential stories (Nasrullah, 2018).

\section{Dynamics of Public Space in the New NTT Facebook Group}

The NTT Baru Facebook Group provides an online communication space for members to interact and share information quickly. The results of observations on posts in this Group found that during March 2020, netizens in NTT discussed issues related to public services and social issues, especially in the health and environment sectors. One of them is the issue of handling Covid-19.

In the early days of the Covid-19 pandemic, netizens who were members of the New NTT Facebook Group did not miss submitting various suggestions regarding the handling of Covid-19. Through this social media, users provide opinions, suggestions, and input to the NTT Provincial Government to take decisive steps to reduce and break the chain of the spread of Covid-19.

The following is the post of Sef, a user in the NTT Baru Facebook group, on 28 March 2020. The post received 1.2 thousand likers and 409 comments. 


\section{Sef $>$ NTT BARU}

28 Maret $\cdot(\theta$

Selamat malam bapak gubernur mohon maaf sesuai data covid -19 di Indonesia

Yang tercatat :

1.155 covid kasus.

Yg sembuh 59 orang .

Kematian 102 orang.

Maka sesuai dengan data yang terlampir di atas kami masyarakat NTT

tidak mengurangi rasa hormat dalam hal ini tidak bermaksud

mengintruksi bapak atau kami mengambil alih dalam ini menangani

covid-19 penyakit yang saat ini mengkuatirkan kita semua.

Namun kami sebagai warga NTT meminta bapak dengan hormat

untuk bisa menghentikan semua kapal maupun pesawat yang masuk d

NTT karena ini sangat membahayakan SE- masyarakat NTT dalam hal

ini penyakit virus Corona. karena kebanyakan penyakit tersebut di

bawah dari luar. maka, hal ini perlu bapak gubernur mengambil

tindakan untuk menghentikan sementara kapal maupun pesawat

yang beroperasi d NTT

Karena NTT masih negatif dgn penyakit Corona sehingga Jangan

menunggu sampai terjadi baru mengambil tindakan artinya bertindak sebelum terjadi .

Usul dari kami masyarakat NTT mohon bapak pertimbangan dan

semoga suara kami yang kami hantarkan melalui tulisan ini semoga

bapak dapat membaca.

Mohon maaf jika tulisan ini tidak menyenangkan hati mulia bapak

gubernur.

Salam: NTT satu hati

Figure 2. A post by a member of the New NTT Facebook group about Covid-19

This post is commented on by netizens or other group members with various views. The following is a mapping of netizens' attitudes or opinions about the proposed handling of Covid-19 in NTT based on the post of one of these users:

Table 1. Mapping of group members' attitudes regarding the issue of handling Covid-19

\begin{tabular}{llll}
\hline No. & User Name & Comment & Attitude of User \\
\hline 1 & R & $\begin{array}{l}\text { Strongly agree with this opinion. } \\
\text { Indeed as citizens, especially in NTT, } \\
\text { we really hope that your policies are } \\
\text { in line with the expectations of the } \\
\text { people, thanks }\end{array}$ & $\begin{array}{l}\text { Supporting Sef's } \\
\text { proposal for the NTT } \\
\text { provincial government } \\
\text { to issue a policy of } \\
\text { closing access to and } \\
\text { from the NTT region }\end{array}$ \\
\hline 2 & AM & $\begin{array}{l}\text { Strongly agree... but all ports cannot } \\
\text { be closed completely because ships or } \\
\text { planes loaded with fuel,... or drugs } \\
\text { must continue to operate... }\end{array}$ & $\begin{array}{l}\text { Support Sef's proposal } \\
\text { but exceptions for } \\
\text { logistical and health } \\
\text { purposes }\end{array}$ \\
\hline 3 & A & $\begin{array}{l}\text { Later ... what to eat ... if all the ships } \\
\text { stop ... how about the distribution of } \\
\text { goods ... }\end{array}$ & Does not support \\
& & $\begin{array}{l}\text { We are disappointed btl2 because } \\
\text { until now ships and planes still roam }\end{array}$ & Support \\
\hline 4 & YMK & & \\
\hline
\end{tabular}




\begin{tabular}{|c|c|c|c|}
\hline No. & User Name & Comment & Attitude of User \\
\hline & & $\begin{array}{l}\text { freely while instructing residents not } \\
\text { to leave the house and avoid crowds. } \\
\text { I suppose that at the port there is not a } \\
\text { crowd? }\end{array}$ & \\
\hline 5 & EL & $\begin{array}{l}\text { Agree, I am a native of Flores, I also } \\
\text { happen to be currently domiciled in } \\
\text { Palu, Central Sulawesi. According to } \\
\text { my information I got in Palu that two } \\
\text { people were positive for Covid } 19 \text {... } \\
\text { and the patient was a person who had } \\
\text { just come from outside the city, } \\
\text { namely Jakarta ... }\end{array}$ & Support \\
\hline 6 & $\mathrm{~J}$ & $\begin{array}{l}\text { Also, remember that we are our } \\
\text { source of rice from Sulawesi. If the } \\
\text { port is closed, imagine that the price } \\
\text { of rice will be high }\end{array}$ & Does not support \\
\hline 7 & $\mathrm{Se}$ & $\begin{array}{l}\text { Indonesia is getting more positive day } \\
\text { by day for the Coronavirus, we all } \\
\text { need to be on alert, meaning that we } \\
\text { have to prepare an umbrella to protect } \\
\text { you }\end{array}$ & Support \\
\hline 8 & ST & $\begin{array}{l}\text { I happen to be migrants in Java, I } \\
\text { really agree with this post, I hope that } \\
\text { people who have the same voice, if } \\
\text { you have the capacity or are close to } \\
\text { the pro-professional, can immediately } \\
\text { deliver the proposal, considering that } \\
\text { this virus is very rapidly transmitting. } \\
\text { Best regards for all basudara (kins) } \\
\text { from overseas lands. }\end{array}$ & Support \\
\hline 9 & MS & $\begin{array}{l}\text { Until now, there has not been a } \\
\text { sterilization room at the airport and } \\
\text { the port... is it the local government } \\
\text { or the aerospace authorities that do } \\
\text { not pay for the procurement of } 1 \\
\text { sterilization room at the airport and at } \\
\text { the port? So those who come to NTT } \\
\text { have to leave the sterilization room } \\
\text { first. The owner has not taken the } \\
\text { items that have passed through the } \\
\text { sterilization room }\end{array}$ & Support \\
\hline 10 & MS & $\begin{array}{l}\text { The governor/mayor's policy must be } \\
\text { firm in stopping/closing their } \\
\text { territorial authority's airports. } \\
\text { Hopefully this will be heard by the } \\
\text { governor }\end{array}$ & Support \\
\hline
\end{tabular}




\begin{tabular}{|c|c|c|c|}
\hline No. & User Name & Comment & Attitude of User \\
\hline 11 & $\mathrm{E}$ & $\begin{array}{l}\text { Do not agree, think about rice, etc., } \\
\text { everything comes from Java and } \\
\text { South Sulawesi. If the MPA is } \\
\text { prohibited from eating what ntt } \\
\text { [NTT] people eat? }\end{array}$ & Does not support \\
\hline 12 & ST & $\begin{array}{l}\text {... the governor does not have the } \\
\text { authority to close all access (planes, } \\
\text { ships etc.). If he has the authority now } \\
\text { it is with the regents and mayors to } \\
\text { prepare ODP data, PDP etc., to be } \\
\text { conveyed to the central government } \\
\text { (Ministry of Health) for reference } \\
\text { changes to the Covid zone map which } \\
\text { will be used by the president's office } \\
\text { to be wise in closing all access } \\
\text { through the consideration of the } \\
\text { central DPR which is their authority. } \\
\text { Because to close all household } \\
\text { access, there is also a negative } \\
\text { impact, if a SHIP does not enter it is } \\
\text { clear rice, sugar, coffee and others are } \\
\text { not available in the weekly and daily } \\
\text { markets as well as no gasoline and } \\
\text { kerosene either. Where do people } \\
\text { WANT to get you? All of a mess later } \\
\text {... }\end{array}$ & Does not support \\
\hline
\end{tabular}

Table 1 above shows that netizens from various backgrounds gather in a virtual room to discuss problems that are being experienced by almost all people in the world, namely the Covid-19 pandemic. The various opinions of netizens who are members of the New NTT Facebook group are generally grouped into two views. First, an attitude that supports the suggestion of a Facebook user named Sef that the NTT Provincial Government closes access in and out of air and outbound transportation from and outside NTT Province. Second, a less supportive attitude by conveying the side effects if the government closes airports and seaports.

Of course, the virtual discussion that was built is expected to be conveyed well in the ears of the Governor and Deputy Governor of NTT. The anxiety of netizens represents the feeling of the grassroots community that the situation of the people in NTT will get worse if the Provincial Government does not take strategic steps to cut the spread of the Corona Virus.

Therefore, the people who are members of this Facebook group seem to be trying hard to provide input on what the NTT Provincial Government should do. Various discourses and narratives also develop in virtual space, starting from the narrative of airport closure, airport sterilization, protecting NTT residents, to logistical supply concerns.

However, apart from these casual chats on social media, Facebook users actually show a symbolic meaning. in the perspective of communication science. In the context 
of political communication, for example, this intense virtual discussion clearly reflects the process of conveying information regarding political aspirations as part of civil society to the government. Therefore, social media presence in this context has succeeded in placing the community as an actor of political communication.

As political communicators, citizens seek to build various discourses related to public service issues and discuss the government's role as the highest authority in regulating the joints of social and state life, including dealing with the spread of Covid19. The discourse that occurs in this public cyberspace is of course built within the framework of generating public opinion.

Therefore, the dynamics of opinion, both pros and cons, often color the virtual discussion space in the NTT Baru Facebook group. It reflects the practice of Indonesian society in general, especially in the reformation era that is thick with the dynamics of opinion. A representation of the characteristics of democracy a la Indonesian society in general, that is, freedom of opinion to fight for the public interest without restraint by the state indicates the good functioning of the Pancasila democracy practiced by Indonesia. Therefore, conveying aspirations in the form of suggestions or input to the government is evidence of the ongoing role and function of civil society control over the continuity of the government (Nasution, 2020).

Moreover, the Pancasila democratic climate encourages and guarantees everyone to openly convey their views and opinions, including in social media (Syahputra, 2017). This democratic tradition has also given birth to the expansion of the role of social media itself. If the essence of the existence of social media was only for social networking, now it has undergone a shift in function. Social media has changed its function to become one of the instruments in building social mobilization in society (Nanabhay \& Farmanfarmaian, 2011).

In the practice of democratic life, everyone can openly and freely (but still have to be responsible) convey their views and perspectives, including through social media. Especially when people consider that access to various political communication channels is relatively limited, social media has turned into a forum for netizens to express their various opinions, perspectives, and aspirations. (Lee, So, Lee, Leung, \& Chan, 2018). In this context, social media has a role in strengthening the practice and dynamics of democracy in society (Danju, Maasoglu, \& Maasoglu, 2013). This means that social media is able to change democratic practices in Indonesia. The community then plays a role as a political actor in conveying their aspirations online and is involved in monitoring government performance (Simarmata, 2014).

In addition to discussing health issues (Covid-19), during March 2020, citizens also through the New NTT Facebook group discussed other social issues, namely environmental issues. For example, one of the netizens with the initials MAMA on 1 March, 2020 informed the public about the alleged practice of illegal logging in a village in Timor Tengah Selatan (TTS) Regency. The post that gets 245 likes and 64 comments and presented in full in Figure 3 below: 


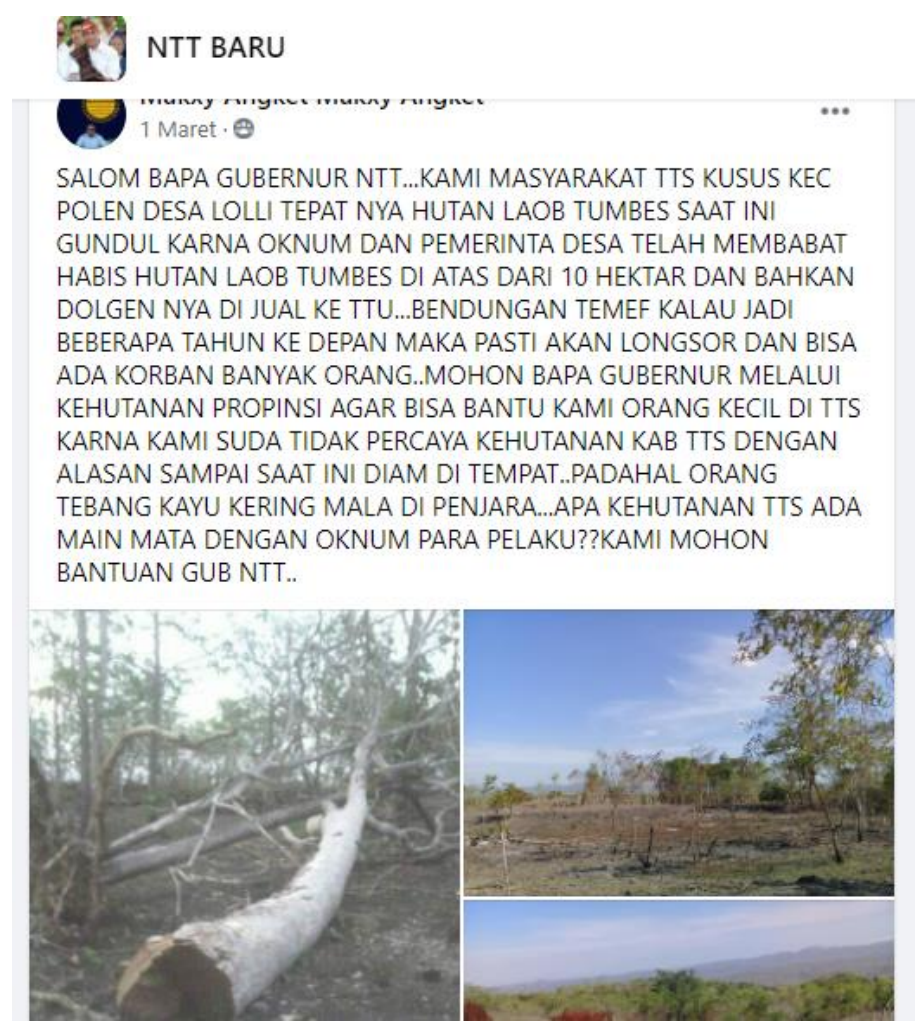

Figure 3. Posts in the NTT Baru Facebook group about alleged forest

This post received various responses including summarized in table 2 the following:

Table 2. Warganet comments and researchers' subjective interpretations of information on alleged logging practices in TTS

\begin{tabular}{|c|c|c|c|}
\hline No. & User Name & Comment & $\begin{array}{l}\text { Researcher's Subjective } \\
\text { Interpretation }\end{array}$ \\
\hline 1 & $\mathrm{BD}$ & $\begin{array}{l}\text { We hope that way... don't let } \\
\text { the poor people suffer the } \\
\text { bad effects. }\end{array}$ & $\begin{array}{l}\text { BD is worried that it is the poor } \\
\text { people who feel the bad impact of } \\
\text { illegal logging practices. }\end{array}$ \\
\hline 2 & KA & \#Walhi_NTT & $\begin{array}{l}\text { KA would like to forward this } \\
\text { post to Walhi (NGO Wahana } \\
\text { Lingkungan Hidup NTT) to get a } \\
\text { response regarding suspected } \\
\text { cases of forest destruction. }\end{array}$ \\
\hline 3 & AW & $\begin{array}{l}\text { In SBD District it is also } \\
\text { worse }\end{array}$ & $\begin{array}{l}\text { AW complained about the same } \\
\text { thing happening in other districts } \\
\text { in Southwest Sumba (SBD). }\end{array}$ \\
\hline 4 & VL & $\begin{array}{l}\text { If humans are greedy in } \\
\text { taking the results of nature ... } \\
\text { then it is only a matter of } \\
\text { time for natural disasters to } \\
\text { occur, so don't blame nature. }\end{array}$ & $\begin{array}{l}\text { VL reminded the importance of } \\
\text { maintaining natural balance in } \\
\text { order to avoid natural disasters }\end{array}$ \\
\hline 5 & $\mathrm{AF}$ & $\begin{array}{l}\text { No wonder the rainfall in } \\
\text { TTS is decreasing.... }\end{array}$ & $\begin{array}{l}\text { AF also linked the relationship } \\
\text { between deforestation and } \\
\text { reduced rainfall intensity in TTS. }\end{array}$ \\
\hline
\end{tabular}




\begin{tabular}{|c|c|c|c|}
\hline No. & User Name & Comment & $\begin{array}{c}\text { Researcher's Subjective } \\
\text { Interpretation }\end{array}$ \\
\hline 6 & $\mathrm{ZP}$ & $\begin{array}{l}\text {... Do you have any } \\
\text { evidence, maybe photos or } \\
\text { videos of people who cut the } \\
\text { forest, why? So that we can } \\
\text { continue to related agencies } \\
\text { in the province }\end{array}$ & $\begin{array}{l}\text { According to } \mathrm{ZP} \text {, if the case of } \\
\text { vandalism is strengthened by } \\
\text { strong evidence, it can be } \\
\text { reported to the authorities }\end{array}$ \\
\hline 7 & $\mathrm{MC}$ & $\begin{array}{l}\text { Actions that have deviated } \\
\text { from state regulations ... }\end{array}$ & $\begin{array}{l}\text { MC wants to show his attitude } \\
\text { that the case raised is an act that } \\
\text { is not praiseworthy and violates } \\
\text { the rules }\end{array}$ \\
\hline 8 & $\mathrm{EN}$ & $\begin{array}{l}\text { Wow ... maybe that's one of } \\
\text { the business sectors of the } \\
\text { village community there }\end{array}$ & $\begin{array}{l}\text { EN regrets if the forest clearing is } \\
\text { a form of Bumdes business in the } \\
\text { village. }\end{array}$ \\
\hline 9 & $\mathrm{KM}$ & $\begin{array}{l}\text { forest is currently being } \\
\text { treated and managed .. for the } \\
\text { prevention of natural } \\
\text { disasters ... for the sake of the } \\
\text { area ... DO NOT ENTER } \\
\text { THE PRIVATE PACKAGE } \\
\text { OF THE REGIONAL HEAD } \\
\text {... if YES ... the indication is } \\
\text { abuse of authority ... it can be } \\
\text { processed [legally] }\end{array}$ & $\begin{array}{l}\text { KM wants to remind that natural } \\
\text { resources including forests should } \\
\text { be managed for the sake of } \\
\text { regional prosperity. }\end{array}$ \\
\hline 10 & MP & $\begin{array}{l}\ldots . \text { is very HEAVY if like } \\
\text { you say that there are EYE- } \\
\text { PLAYING BUSINESSES } \\
\text { with the GOVERNMENT.... } \\
\text { Then the people want to die } \\
\text { [or] live NOT PUSING } \\
\text { [ignored] }\end{array}$ & $\begin{array}{l}\text { MP also reminded that the people } \\
\text { would be the victims if the } \\
\text { government did not take firm } \\
\text { steps against cases of illegal } \\
\text { logging according to the } \\
\text { prevailing regulations. }\end{array}$ \\
\hline 11 & A & $\begin{array}{l}\text { That is the one who chooses } \\
\text { KPLA Desa ... the one who is } \\
\text { evaluating [choosing], so that } \\
\text { the head of village can } \\
\text { choose to think about his } \\
\text { own stomach, not thinking in } \\
\text { the future... }\end{array}$ & $\begin{array}{l}\text { According to A, the local Village } \\
\text { Head should have exercised } \\
\text { control so that illegal practices } \\
\text { would not occur. }\end{array}$ \\
\hline 12 & $\mathrm{M}$ & $\begin{array}{l}\text { I have reported [Pemkab } \\
\text { TTS] but there is no response } \\
\ldots \\
\text { We want to complain about } \\
\text { where else is the governor ... } \\
\text { because Loli Village is full of } \\
\text { milk and honey but the } \\
\text { Ampupu wood has been cut } \\
\text { down and we are worried that }\end{array}$ & $\begin{array}{l}\text { M really hopes that there will be } \\
\text { solutions from the Governor of } \\
\text { NTT. }\end{array}$ \\
\hline
\end{tabular}




\begin{tabular}{ccc}
\hline No. User Name & \multicolumn{1}{c}{ Comment } & $\begin{array}{c}\text { Researcher's Subjective } \\
\text { Interpretation }\end{array}$ \\
\hline & $\begin{array}{l}\text { the bees will switch to TTU } \\
\text { and we are left in TTS ... }\end{array}$ \\
\hline
\end{tabular}

Table 2 contains the various comments made by netizens on the NTT Baru Facebook group, which originated from a resident report (with the initials MAMA) who allegedly knew the case of illegal logging. This post then trigger to various reactions from other Facebookers. Some netizens want the report to be forwarded to the authorities. Some blame the Polen Village Government and the TTS Regency Government for being deemed not responsive in overcoming forest clearing practice.

Looking at the virtual discussions that occur in cybermedia, it can be said that netizens are maximizing Facebook as an instrument to share information about issues that disturb the comfort around them and require government attention. As shown in Table 2, netizens spontaneously conveyed complaints through virtual public spaces. In short, netizens are trying to take advantage of the virtual space in the NTT Baru Facebook group as a place to talk to one another about the development of the surrounding environment, which is considered disturbing.

Therefore, what is shown by netizens proves that the use of social media, especially Facebook in the context of Indonesian society, is used as a means or a place to express feelings (complaints) in order to get reactions from other netizens. (Jsati, 2016). Confide in each other and then provide responses on social media, which can influence others' communication behavior to also build public opinion in the social media space (Dey, 2020). This can be seen in Table 2, where one user's posting generates complaints and/or confides from other group members. Some have complained about the local government's slow anticipation and talked about similar practices in their area, and some have tried to vent about the possible loss of livelihoods from forest honey bees due to the loss of large trees where bees nest.

On the other hand, the building of public opinion on social media in turn triggers the critical attitude of netizens. Not a few netizens have loudly criticized the government's performance through Facebook's social media(Abbott, 2012). Table 2 shows netizens' comments who blame the Village Government to the TTS Regency Government because they are considered slow in taking action against the perpetrators.

Based on the variety of posts and discussions that have been built up among Facebook users as shown in Figure 2, Table 1, Figure 3, and Table 2, the presence of social media, in this case, the New NTT Facebook group, is really being used as a means building a citizen-style democracy culture. This emerged when conducting indepth interviews with several members of this Facebook group. An informant with the initials HD (46) said that the NTT Baru Facebook group provided space for democracy, namely, political education for all members. In line with this, FN (41) also explained that in a democratic space, this Group is a forum for exchanging ideas, information, and ideas of members. FN provides an example: if the issue raised has academic nuances, it does not get a response. Meanwhile, if the topic of the post is related to public service issues and requires the attention of the governor and deputy governor of NTT Province, it will receive many responses. Other informants,

However, apart from the positive side, discussing the NTT Baru Facebook group also did not escape the negative side. According to JM (49), one of the group admins, there are many comments from netizens that are considered to be injurious to the 
practice of democracy in social media. The following are excerpts from the interview:

"The democracy in this Group is very good, but it is classified as extreme. For example, if they support something, they will fully support it, but if they are opposed, they will issue rather harsh words such as cheater, distort [liar], and so on and frontal without sufficient valid data. Maybe this is influenced by the typical NTT people whose nature is rough and arid, so the delivery is frontal, and there is a lack of valid data ".

In line with the admin, another informant, NM (25), also said. According to him, the NTT Baru Facebook group was too free to express himself so that it sometimes caused divisions. In expressing their opinion, group members often attacked personally, said NM.

In essence, the discussions that took place in the NTT Baru Facebook group were very free. Various views and attitudes of netizens also vary. Some give a positive opinion, and some are the opposite negative opinions.

If the communication phenomenon that occurs in cyberspace is related to the concept of public space as promoted by Habermas, several things can be conveyed. First, the citizens' conversations freely regarding any issue in the NTT Baru Facebook group represent the public space as intended by Habermas. Second, the concept of public space that was promoted by Habermas as a place to talk about anything in a real physical space is now experiencing a shift along with the development of digitalization of technology. Third, the concept of public space in the era of internet-based technology has expanded, where it does not only relies on physical encounters but also switches to virtual public spaces that are now increasingly prevalent and intensively created in cyberspace, especially through social media (Zainal \& Megasari, 2019).

The concept of virtual public space in social media can theoretically be explained from the social construction theory of technology. According to the viewpoint of the social construction theory of technology, social media's presence does not necessarily shape human communication behavior and actions. On the contrary, it is humans who treat technology according to their will and interests (Yousefikhah, 2017). Humans are also the ones who expand the existence of social media as new technology, or a means to build virtual public spaces filled with dynamics. Not only is ethical democracy shown in the social media space, but also many practices that hurt democracy with comments that attack other netizens. If the essence of social media was initially limited to expanding social networks, but along with the times, social media has expanded its function as a tool to build social and political mobilization.

\section{Symbolic communication politics on the New NTT Facebook group}

The NTT Baru Facebook Group uses a photo or picture of the Governor and Deputy Governor of the Province of Nusa Tenggara Timur (NTT), Viktor Bungtilu Laiskodat and Josef Nae Soi. The use of the image of the First Persons in NTT Province as a profile image symbolically contains a lot of meaning in it. First, from the selection of the images of the two top people in one of the island provinces, it seems as if they want to communicate to the public that this Facebook group is one of the groups that fully support the policies and programs launched by the Governor and Deputy Governor of NTT. This indication can be seen from the way the admin displays photos of the two figures, complete with daily official clothes as public officials in NTT. 


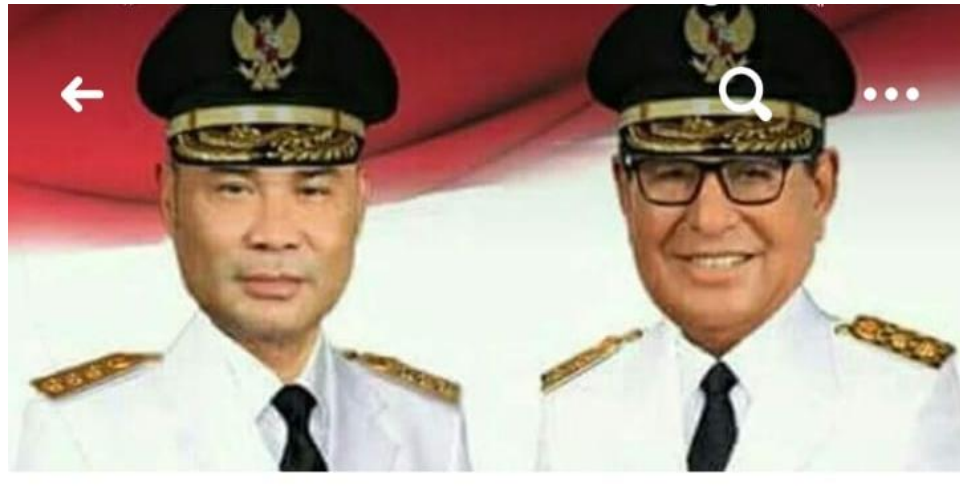

NTT BARU >

GRUP PRIVAT $\cdot 86.783$ ANGGOTA

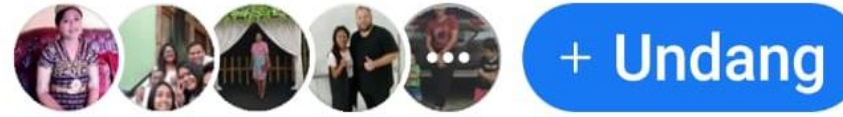

Figure 4. New NTT Facebook group profile photo (source: New NTT Facebook Group, March 2020).

The symbolic meaning of placing the photos of the two top leaders in the scope of NTT Province was also interpreted in a similar vein by several informants. One informant, RB (46 years), stated, "There is a message symbolically from the cover of the Group. Yes, that is what the supporters of Victory-Joss [are called the pair Victor Bungtilu Laiskodat and Josef Nae Soi during the 2018-2023 Governor election event] ".

What was conveyed by RB was also confirmed by the group admin as well as the initiator or founder of the NTT New Facebook group. JM (49 years old) admits that the basis for choosing the image of the Governor and Deputy Governor of NTT as the foreground on this Group's website is to state his side of the two leaders. The following is an excerpt from the interview:

"First, because I am a supporter of the current governor. Second, it must support him because there is hope that NTT is because he is clean, does not corrupt, is Pancasila, is in a political party with the Pancasila ideology, is still young, firm and has everything that NTT needs to become new".

What was conveyed by these two sources was also confirmed by other sources. NT (29) also agrees that this Facebook group is one of the groups created as a form of political support for the Governor and Deputy Governor of NTT.

Other informants also gave similar views on the selection of the photo of the NTT leader. "Because it is a symbol for group members that this is our leader, our choice", said HD (46 years). AD (45 years) also shared a similar view. The woman who works in the entrepreneurial field and lives in Sikumana Village, Kupang City also said, "Because this group is the incarnation of the figures of the two new NTT leaders, namely Viktor Laiskodat and Josef Nae Soi".

Based on these sources' views, it can be said that the existence of a Facebook group called "New NTT" symbolically wants to convey the following message: first, this Group was created by supporters of the governor and deputy elected governor. Second, this Facebook group is intended as a discussion space in conveying opinions and input as a form of moral support for the elected Governor and Deputy Governor's 
leadership. Third, this Facebook group wants to communicate that the followers who are members of the Group are loyal supporters who are ready to make a positive contribution to the policies and programs of the elected Governor and Deputy Governor of NTT for the progress of NTT.

If further analyzed using cybermedia analysis techniques as introduced by Nasrullah, it will look like Table 3 below:

Table 3. Cybermedia analysis of the New NTT Facebook group

\begin{tabular}{|c|c|c|c|}
\hline No. & Analysis Level & $\begin{array}{l}\text { Object of } \\
\text { Analysis }\end{array}$ & Result \\
\hline 1 & $\begin{array}{l}\text { Micro (media } \\
\text { room) }\end{array}$ & $\begin{array}{lr}\begin{array}{l}\text { Structure, media } \\
\text { device, } \\
\text { appearance }\end{array} & \text { and } \\
\end{array}$ & $\begin{array}{l}\text { Photos of the Governor and Deputy } \\
\text { Governor of NTT in full official attire are } \\
\text { placed on the NTT Baru Facebook Group } \\
\text { profile page. Based on interviews with } \\
\text { the admin, this Group was created by } \\
\text { loyal supporters / loyal to the elected } \\
\text { Governor and Deputy Governor (Viktor } \\
\text { Laiskodat and Josef Nae Soi) and did not } \\
\text { represent the NTT Provincial } \\
\text { Government. }\end{array}$ \\
\hline 2 & $\begin{array}{l}\text { Micro (media } \\
\text { document) }\end{array}$ & $\begin{array}{l}\text { Content, aspects } \\
\text { of text/graphic } \\
\text { meaning }\end{array}$ & $\begin{array}{l}\text { The name of the Group reads "New } \\
\text { NTT". Based on the results of in-depth } \\
\text { interviews with the creators of this } \\
\text { Group, the name of the Group has a } \\
\text { meaning related to the vision of NTT's } \\
\text { development, which is experiencing a } \\
\text { paradigm shift from the old NTT to the } \\
\text { new NTT under the leadership of the } \\
\text { current governor and deputy governor. } \\
\text { According to the founder of this Group, } \\
\text { there is optimism that NTT will } \\
\text { experience a transformation and a } \\
\text { paradigm shift from NTT labeled "left } \\
\text { behind" to a changing and advanced } \\
\text { NTT. }\end{array}$ \\
\hline 3 & $\begin{array}{l}\text { Macros (media } \\
\text { objects) }\end{array}$ & $\begin{array}{l}\text { Interaction } \\
\text { between users } \\
\text { that occurs in } \\
\text { cyberspace }\end{array}$ & $\begin{array}{l}\text { Based on the results of interviews and } \\
\text { virtual observations, in general, the } \\
\text { interactions that occur in the NTT Baru } \\
\text { Facebook group are more dominated by } \\
\text { messages containing reports, complaints, } \\
\text { and confidences to the NTT Provincial } \\
\text { Government. }\end{array}$ \\
\hline 4 & $\begin{array}{l}\text { Macro } \\
\text { (experience) }\end{array}$ & $\begin{array}{l}\text { Motives, effects, } \\
\text { and benefits of } \\
\text { media presence. }\end{array}$ & $\begin{array}{l}\text { The results of in-depth interviews } \\
\text { confirm the results of virtual } \\
\text { observations that the motive of the } \\
\text { citizens is that apart from providing } \\
\text { political support for the leadership of the } \\
\text { governor and deputy governor of NTT, }\end{array}$ \\
\hline
\end{tabular}




\begin{tabular}{lll}
\hline No. Analysis Level & $\begin{array}{l}\text { Object of } \\
\text { Analysis }\end{array}$ & Result \\
\hline
\end{tabular}

the existence of this virtual discussion forum is expected to be an instrument that can bridge communication between the NTT provincial government and the community.

Source: (Nasrullah, 2018) and Researcher data processed

The motive for giving political support to the governor and deputy governor's leadership is also evident from the various praises and expressions of pride of citizens on the NTT Baru Facebook group. The following is an example of a screenshot that reflects the positive support by netizens in the NTT Baru Facebook group:

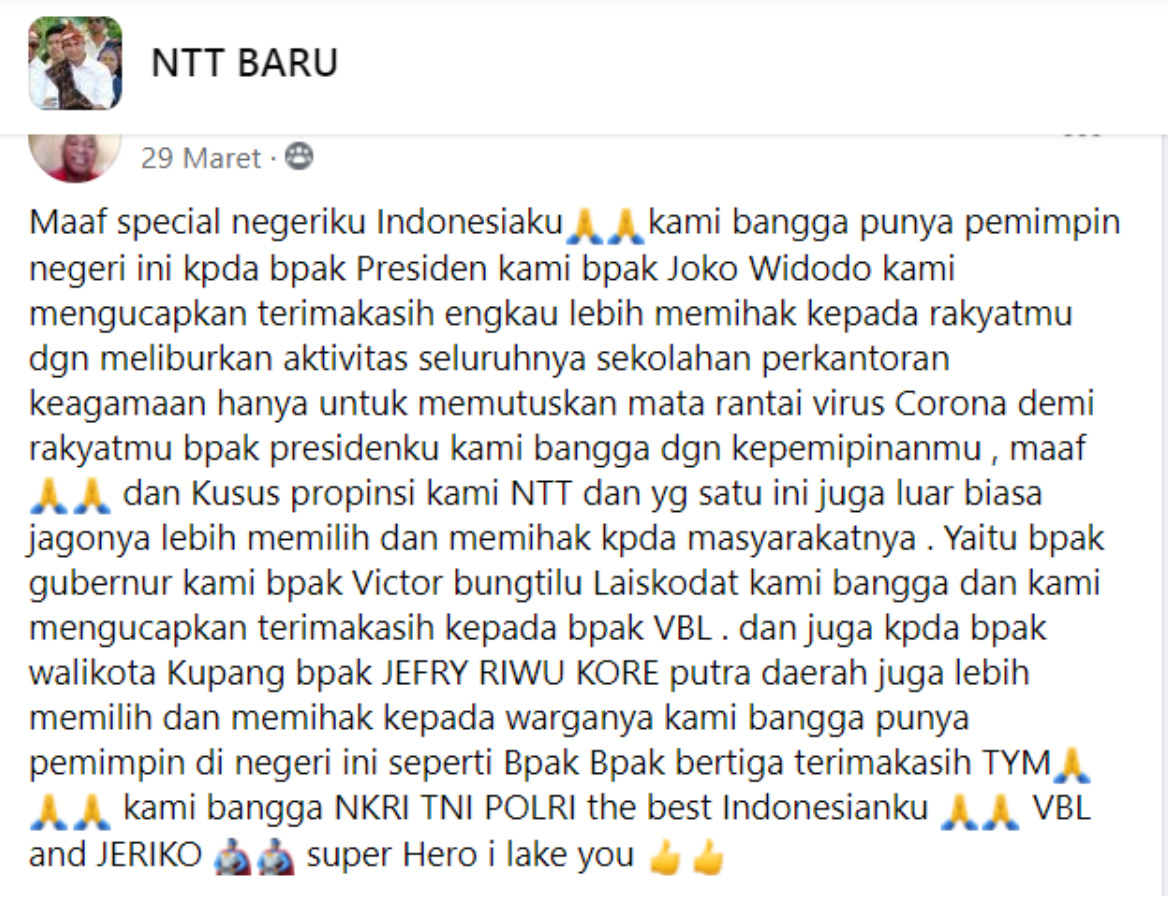

Figure 5. An example of a citizen's post showing support for the NTT governor

The table of cybermedia analysis results on the existence of the NTT Baru Facebook group also provides an illustration of the use of social media as a discursive space in building public opinion and political support. The New NTT Facebook Group, apart from being a forum for the public to convey complaints, share, views, and input to the NTT Provincial Government, also functions to produce public discourse. Social media is an arena for netizens to produce discourse according to their wishes (Syahputra, 2017).

The discourse practices implicit in the posts and comments of netizens on the New NTT Facebook group include moral support for the governor and deputy governor as the right and best leaders for NTT's sociological and geographical conditions. This can be seen from the comments of praise to the governor to informants' answers both as members and founders or group admins.

Moreover, this Facebook group's emergence was initiated by loyal supporters of the governor and deputy governor, Victor Bungtilu Laiskodat and Josef Nae Soi. Therefore, the communication interactions that take place in this virtual space are more 
or less nuanced to provide positive stimuli in the form of moral and political support. This implies that Facebook, as a social media platform, has a role in expanding political communication networks in democratic practice in society (Susanto, 2017). Through Facebook, the digital public space is used as a forum for every citizen to express their views and political support discursively (Zainal \& Megasari, 2019).

\section{Conclusion}

Some conclusions that can be drawn include, first, the NTT Baru Facebook group is a forum for NTT netizens to virtually gather to freely discuss public service issues within NTT Province. Second, the NTT Baru Facebook group becomes a virtual public space for NTT netizens to demonstrate democratic practices as a reflection of the functioning of civil society's control function. Third, the existence of the NTT Baru Facebook group is used as a means of political communication in building social mobilization as a form of moral and political support for supporters of the Governor and Deputy Governor of NTT, Viktor Laiskodat and Josef Nae Soi.

The results of this study have implications for broadening the meaning of the concept of public space as promoted by Habermas. The public space that Habermas introduced as a place where people meet physically has now expanded its meaning. The boundaries of public space do not only include physical meetings in real spaces but also include the dimensions of virtual public spaces along with the development of digitalbased technology, especially the presence of various social media platforms.

\section{Acknowledgements}

This research was funded by DIPA, Faculty of Social and Political Sciences, Nusa Cendana University, Kupang, NTT. Thanks to the Dean of Social Sciences and Undana Chancellor.

\section{References}

Abbott, J. (2012). Democracy@internet.org revisited: Analysing the socio-political impact of the internet and new social media in east Asia. Third World Quarterly, 33(2), 333-357. https://doi.org/10.1080/01436597.2012.666015

APJII. (2019). Laporan Survei: Penetrasi \& Profil Perilaku Pengguna Internet Indonesia. Retrieved from https://apjii.or.id/survei

Budiyono, M. (2016). Media Sosial Dan Komunikasi Politik: Media Sosial Sebagai Komunikasi Politik Menjelang Pilkada Dki Jakarta 2017. Jurnal Komunikasi, 11(1), 47-62. https://doi.org/10.20885/komunikasi.vol11.iss1.art4

Danju, I., Maasoglu, Y., \& Maasoglu, N. (2013). From Autocracy to Democracy: The Impact of Social Media on the Transformation Process in North Africa and Middle East. Procedia - Social and Behavioral Sciences, 81, 678-681. https://doi.org/10.1016/j.sbspro.2013.06.495

Dey, S. (2020). Let There Be Clamor: Exploring the Emergence of a New Public Sphere in India and Use of Social Media as an Instrument of Activism. Journal of Communication Inquiry, 44(1), 48-68. https://doi.org/10.1177/0196859919827319

Habermas, J. (1989). The Structural Transformation of the Public Sphere (Translated Massachusetts Institute of Technology). Cambridge, Massachusetts: The MIT Press.

Hardiman, F. B. (2010). Ruang Publik. Yogyakarta: Kanisius. 
Hastuti, H. B., \& Rahmawati. (2019). Geliat Pemertahanan Budaya Lokal dalam Jejaring Facebook. In F. Gunawan \& H. Hastuti (Eds.), Media Sosial Dan Masyarakat Pesisir: Refleksi Pemikiran Mahasiswa Bidikmisi (pp. 179-187). Yogyakarta: Deepublish.

Heryanto, G. (2018). Media Komunikasi Politik, Relasi Kuasa Media di Pangung Politik. Yogyakarta: IRGiSoD.

https://www.facebook.com/groups/120152055419903. (n.d.). NTT Baru.

Ida, R. (1999). The Social Construction of Technology and the Development of Satellite Telecommunication in Indonesia. (3), 23-30.

Jati, W. R. (2016). Cyberspace, Internet, Dan Ruang Publik Baru: Aktivisme Online Politik Kelas Menengah Indonesia. Jurnal Pemikiran Sosiologi, 3(1), 25. https://doi.org/10.22146/jps.v3i1.23524

Juju, D., \& Sulianta, F. (2010). Hitam Putih Facebook. Jakarta: Elex Media Komputindo.

Kindarto, A. (2010). Efektif Blogging dengan Aplikasi Facebook. Jakarta: Elex Media Komputindo.

Lee, P. S. N., So, C. Y. K., Lee, F., Leung, L., \& Chan, M. (2018). Social media and political partisanship - A subaltern public sphere's role in democracy. Telematics and Informatics, 35(7), 1949-1957. https://doi.org/10.1016/j.tele.2018.06.007

Li, B. (2008). American Libraries and the Internet: The Social Construction of Web Appropriation and Use. Youngstown, New York: Cambria Press.

Nanabhay, M., \& Farmanfarmaian, R. (2011). From spectacle to spectacular: How physical space, social media and mainstream broadcast amplified the public sphere in Egypt's "Revolution." Journal of North African Studies, 16(4), 573603. https://doi.org/10.1080/13629387.2011.639562

Nasrullah, R. (2018). Riset Khalayak Digital: Perspektif Khalayak Media Dan Realitas Virtual Di Media Sosial. Jurnal Sosioteknologi, 17(2), 271. https://doi.org/10.5614/sostek.itbj.2018.17.2.9

Nasution, L. (2020). Hak Kebebasan Berpendapat dan Berekspresi Dalam Ruang Publik di Era Digital. Buletin Hukum Dan Keadilan, Volume 4, 37-48.

Prasetyo, A. (2012). Menuju Demokrasi Rasional: Melacak Pemikiran Jurgen Habermas Tentang Ruang Publik. Jurnal Ilmu Sosial Dan Ilmu Politik, 16(2), 169-185.

Simarmata, S. (2014). Media Baru, Ruang Publik Baru, Dan Transformasi Komunikasi Politik Di Indonesia. InterAct-Journal on Communication, 3(2), 18-36. Retrieved from http://ojs.atmajaya.ac.id/index.php/fiabikom/index

Sulianta, F. (2015). Keajaiban Sosial Media. Jakarta: Elex Media Komputindo.

Sulthan, M., \& Istiyanto, S. B. (2019). Model Literasi Media Sosial Bagi Mahasiswa. Jurnal ASPIKOM, 3(6), 1076. https://doi.org/10.24329/aspikom.v3i6.280

Susanto, E. H. (2017). Media Sosial Sebagai Pendukung Jaringan Komunikasi Politik. Jurnal ASPIKOM, 3(3), 379. https://doi.org/10.24329/aspikom.v3i3.123

Syahputra, I. (2013). Rezim Media: Pergulatan Demokrasi, Jurnalisme, dan. Infotainment dalam Industri Televisi. Jakarta: Gramedia Pustaka Utama.

Syahputra, I. (2017). Demokrasi Virtual Dan Perang Siber Di Media Sosial: Perspektif $\begin{array}{llll}\text { Netizen Indonesia. Jurnal } & 457 .\end{array}$ https://doi.org/10.24329/aspikom.v3i3.141

W.O. Raliana, Bahtiar, R. S. (2018). Dampak Penggunaan Facebook terhadap Perilaku Remaja (Studi di Desa Sampuabalo Kecamatan Siotapina Kabupaten Buton). Neo Societal, 3(2), 510-517. https://doi.org/http://dx.doi.org/10.33772/jns.v3i2.4055 
Wazis, K. (2017). Facebook Sebagai Media Komunikasi Poltik: Analisis Media Siber Facebook Dr. Faida, MMR. Jurnal Ilmu Komunikasi, 8(1), 38-46.

Websindo. (2019). Indonesia Digital 2019: Internet. Retrieved from https://websindo.com/indonesia-digital-2019-internet

Wijayanti, Y. T. (2020). Radicalism Prevention through Propaganda Awareness on $\begin{array}{lllll}\text { Social Media. Jurnal } & 142 .\end{array}$ https://doi.org/10.24329/aspikom.v5i1.501

Yousefikhah, S. (2017). Sociology of innovation: Social construction of technology perspective. AD-Minister, (june), 31-43. https://doi.org/10.17230/ad-minister.30.2

Zainal, F., \& Megasari, N. F. (2019). Mempolitisasi Ruang Virtual: Posisi Warga-Net dalam Praktik Demokrasi Digital di Indonesia. Jurnal Ilmiah Manajemen Publik Dan Kebijakan Sosial, 306(1), 306-326. 